\title{
論文
}

\section{Properties of IPNs of Epoxy Resin/Bismaleimide-Allylester Copolymer}

\author{
Katsuyoshi IIsAKA
}

\author{
Materials $\mathcal{E}$ Electronic Devices Laboratory, Mitsubishi Electric Corporation, \\ 1-1, Tsukaguchi-Honmachi 8-chome, Amagasaki, Hyogo, 661 Japan
}

Interpenetrating polymer networks (IPNs) were prepared from anhydride-cured epoxy resin and bismaleimide (BMI) coreacted with triallyltrimellitate (TAT), triallylisocyanurate (TAIC), and diallylisophthalate (DAP), under the same gelling conditions for both the epoxide resin and BMI-allylester comonomer. Dynamic mechanical properties of the IPNs were measured over the temperature range from $\mathrm{rccm}$ temperature to $400^{\circ} \mathrm{C}$. In addition, tensile and thermal degradation properties were measured for these IPNs. The rubbery modulus and primary dispersion temperature $\left(T_{\alpha}\right)$ due to the cured epoxy resin considerably increased with loading of BMI-allylester component. The value of $T_{\alpha}$ exhibited an asymptotic behavior at high loading, the value increasing in the order of BMI-TAT, -TAIC, and -DAP. The modulus behavior in the rubber state followed approximately the Budiansky's equation and suggested the formation of IPN. The difference among the asymptotic values of $T_{\alpha}$ for each series can be explained in terms of polar-nonpolar solubilities of the components. The most efficient and major increase in $T_{\alpha}$ which occured at about $50 \mathrm{wt} \%$ of BMIallylester component, is based upon an enhanced miscibility between both components as a result of interpenetration. The effects of interpenetration brought about maxima in tensile strength significantly higher than the tensile strength of the component networks and some improvement in thermal resistance at about $50 \mathrm{wt} \%$ of BMI-allylester component.

Key words: Interpenetrating Polymer Networks / Epoxy Resin / Bismaleimide-Allylester Copolymer / Dynamic Mechanical Properties / Tensile and Thermal Degradation Properties

\section{エポキシ樹脂/ビスマレイミド・アリルエステル共重合体系 IPN の性質}

飯阪捷義*

（原稿受理：1991年 3 月18日）

\section{1. 緒言}

複合材料用マトリックスレジンに要求される重要な特性として, 耐熱性や機械的性質の他に, 加工性の良い事が挙げられる。例え ば，ラミネート形成時，レジンの強化材中への浸透が十分行われ， 加熱硬化後, ボイドの発生があってはならない，代表的な耐熱性 高分子であるポリイミドの中, 付加重合型のビスマレイミドは, カプトンのような縮合重合型ポリイミドと比べて揮発分の副生を

*三菱電機(株)材料研究所 $\mathbf{T} 661$ 尼崎市塚口本町 $8-1-1$
伴わず，易加工性のレジンとして，近年注目されている。しかし， その単独重合体は，高度の橋か訬密度により極めて脆いという久 点をもっている。このため, 例えばマレイミド二重結合への芳香 族ジアミンの付加によるスペーサの導入等が行われ1) 4), ケルイ ミド6011) (ローヌ・プーラン社) や，M7514) (テクノケミエ社) として商用化されている。しかしながら，これら樹脂により，ラ ミネートを形成する際には，N-メチルピロリドンやジメチルホ ルムアミドの上うな高沸点溶剤を必要とし ${ }^{5}$, ボイドの発生や溶 剤残留により，電気的性質や機械的性質が損なわれやすいという 
難点がある.

一方, エポキシ樹脂は周知のように, 適度の耐熱性とバランス の良い機械的性質を有し，硬化剤の選択により低粘度化が図れる。 従って, 上記ビスマレイミドとエポキシ樹脂とのブレンドは, 耐 熱性に優れ，機械的性質の良い無溶剤の含浸レジンを与えるもの と期待される．前報に扔いて，この様なブレンド系について，動 的粘弾性研究を行い, 中間の組成領域でガラス転移に相当する主 分散温度とゴム弾性率に関し, 效率の良い上䒜を観察した ${ }^{6)}$ 。こ れはビスマレイミドが付加反応，そしてエポキシ樹脂が縮合反応 というように，それぞれ異なる反応機構によって，高分子網目が 形成され, 相互貫通高分子網目 (IPN : Interpenetrating Polymer Network) の形成効果によるものと考察した. IPN の形成は, 実 用性質として重要な引張り強度や熱分解特性に関し, 相乗作用に より顕著に改善される場合のある事が報告されている7 ${ }^{7) ~ 9) . こ の ~}$ 研究では，該ブレンドについて前報と比べ，動的粘弾性測定をよ り高温領域をで広げ, 動的粘弾性挙動のより詳細な解明と, 引張 りおよび熱分解挙動を調べる事を目的とした.

試料は前報と同様 ${ }^{6}$, エポキシ樹脂系として，ビスフェノール $\mathrm{A}$ 型エポキシ樹脂/メチルテトラヒドロ無水フタル酸を, ビスマ レイミド系として，4,4'-ジマレイミドジフェニルメタン (BMI) と, エポキシ樹脂への溶解性を高めるため BMI と共重合可能な アリルェステルとの等量混合物で，アリルェステルとしては，エ ポキシ樹脂網目鎖との相互作用性を変えたものとして，トリアリ ルイソシアヌレート (TAIC), トリアリルトリメリテート (TAT) およびジアリルイソフタレート (DAP) を使用した。な抮，IPN の調製は両成分の相溶性が最も高まるよう，それぞれの樹脂のゲ ル化時間がほぼ同じ重合条件で行った。

\section{2. 実 験}

\section{$2 \cdot 1$ 試料の調製}

エポキシ樹脂系は， ジグリシジルエーテルビスフェノールーA (エピコート 828, シェル製), 硬化㓮としてメチルテトラヒドロ 無水フタル酸 (HN 2200, 日立化成製), 硬化促進剤としてベン ジルジメチルアミン（和光純薬製）を，それぞれ使用した。 ビス マレイミド・アリルエステル系は，それぞれ Fig. 1 亿示す化学 構造を持った $4,4^{\prime}$-ジマレイミドジフェニルメタン $(\mathrm{BMI})(\mathrm{mp}=$ $156^{\circ} \mathrm{C}$ ，東京化成製），TAIC (東京化成製)，TAT (東京化成製) および DAP (和光純薬製) と, 開始剤としてジクミルパーオキ サイド（和光純薬製）を，それぞれ使用した。エポキシ樹脂系を 除く他の試薬はすべて化学一級であった，試料の調製は, 等量の $\mathrm{BMI}$ とアリルエステル混合物を約 $160^{\circ} \mathrm{C}$ 飞加熱溶解後, 約 $100^{\circ} \mathrm{C}$ に冷却し, 開始剤 $1.0 \mathrm{wt} \%$ を加える。一方, 化学等量の硬化剂 と促進剂 $1.0 \mathrm{wt} \%$ を含むエポキシ樹脂混合物を約 $60^{\circ} \mathrm{C}$ に加熱し, これに前記加熱した BMI 混合物を各種重量割合で加え, 靦拌す る. 該混合物をスペーサを含むガラス板に注型し， $140^{\circ} \mathrm{C} \times 4 \mathrm{~h}$, $200^{\circ} \mathrm{C} \times 16 \mathrm{~h}$ ，続いて $280^{\circ} \mathrm{C} \times 1 \mathrm{~h}$ ，加熱硬化させた．ここで開始 剤 $1.0 \mathrm{wt} \%$ を含む $\mathrm{BMI} /$ アリルエステル混合物と，促進剤 1.0 wt \% を含むエポキシ樹脂混合物のゲル化時間は, $140^{\circ} \mathrm{C}$ 亿おいて いずれもほぼ同じ約 3 分であった。陚料名を E・MTAT, E . MTAIC, E・MDAP とし, 末尾の数字は $\mathrm{BMI} /$ アリルェステル 混合物の含有 $w t \%$ を示す.

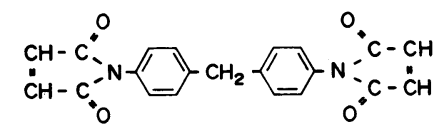

4,4-dimaleimide diphenylmethane (BMI)<smiles>C=CCCOC(=O)c1ccc(C(=O)OCCCC)cc1</smiles>

triallyltrimellitate (TAT)

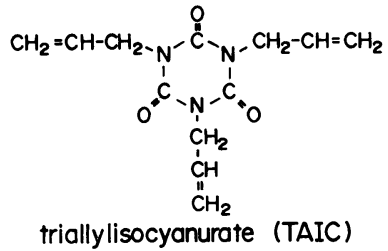

Fig. 1 Chemical structure.

\section{$2 \cdot 2$ 測 定}

動的粘弾性は, 粘弾性スペクトロメータ (VES-F3, 岩本製) により, 周波数 $3.5 \mathrm{~Hz}$, 室温 $400^{\circ} \mathrm{C}$ の温度範囲で, 貯蔵弹性率 $E^{\prime}$, 損失弾性率 $E^{\prime \prime}$, 括よび $\tan \delta$ を求めた。 引張り特性は, テ ンシロン (UTM-II-20, 東洋ボールドウィン製) により, 引張り 速度 $4 \mathrm{~mm} /$ 分で, 室温 $150^{\circ} \mathrm{C}$ おび $200^{\circ} \mathrm{C}$ 温度で, 熱分解特性 は熱天科 ( $\mathrm{TG}$, 理学電機製) により空気中, 升温速度 $10^{\circ} \mathrm{C} /$ 分で, $600^{\circ} \mathrm{C}$ をとれぞれ測定した。

\section{3. 結果と考察}

\section{$3 \cdot 1$ 動的粘弾性}

Fig. 2 に代表例として, E・MTAT 系について, 動的粘弾性 測定結果を示す.エポキシ樹脂硬化物は，ガラス・ゴム転移に相 当する主分散が，約 $150^{\circ} \mathrm{C}(\tan \delta$ ピーク温度）に現れ，一方， BMI・アリルェステル共重合体の場合, E・MTAT-100 は約 380 ${ }^{\circ} \mathrm{C}$ に明膫な分散が現れたが， E・MDAP-100 では, 約 $350^{\circ} \mathrm{Cから}$ $E^{\prime}$ の急激な低下が始まってそのまま試料の切断に至り，また $\mathrm{E}$. MTAIC-100 では，ここで行った測定温度範囲に拈いてなんらの 分散も観察されなかった。な拈，エポキシ樹脂硬化物の $E^{\prime}$ 対温度 挙動は, 主分散に相当する温度域での $E^{\prime}$ の大きな低下後, 約 180 $\sim 280^{\circ} \mathrm{C}$ の温度範囲でゴム平坦領域を示し, その後 $300^{\circ} \mathrm{C}$ 近辺から 再び大きな減少を示し, 試料が切断して測定不可能となった。両 樹脂のブレンド試料の場合, $\tan \delta$-温度曲線からいずれの系も単 一の分散が観測され, BMI 混合物量の增加とともに, 高温側一 大きなシフトを示した. 一方, $E^{\prime}$ に関し $\tan \delta$ 分散に相当する 温度域で $E^{\prime}$ の大きな低下があり，その低下量は BMI 混合物量 の增加とともに急激に小さくなった。 そして高温側に打いて, BMI 混合物量に依存せず，どのブレンド試料に扒いても，エポ キシ樹脂硬化物の場合とほぼ同じ温度の $300^{\circ} \mathrm{C}$ 近辺から, 再び大 きな減少を示し，測定不可能となった。エポキシ樹脂硬化物の熱 


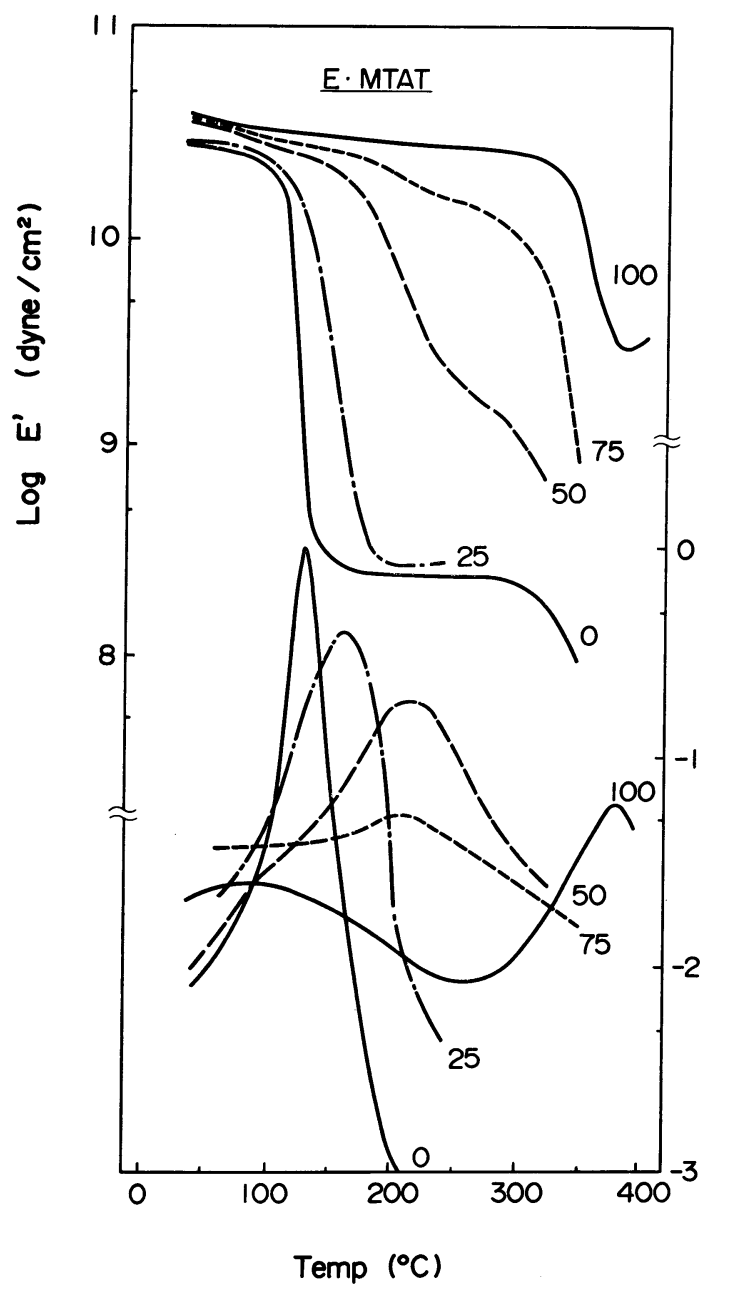

Fig. 2 Temperature dependences of storage modulus $E^{\prime}$ and $\tan \delta$ for series of E MTAT. The numbers on the curves denote wt $\%$ of the BMI-TAT.

分解が約 $300^{\circ} \mathrm{C}$ の温度で始まる事から，この高温側に拈ける $E^{\prime}$ の低下は，エポキシ樹脂成分の熱劣化が関与しているものと考兄 られる。な执, BMI 混合物量50および $75 \mathrm{wt} \%$ の試料の場合に, エポキシ樹脂硬化物の主分散温度とほ注同じ温度域で小さな $E^{\prime}$ の低下が観測されたが，この温度域は BMI ・ アリルエステル共 重合体の低温分散温度域でもあり，この小さな分散機構について 現在のところ明瞭な説明は困難である。ブレンド試料の主転移後 の眝蔵弾性率 $E^{\prime}$ 扤よび主分散温度 $\left(T_{\alpha}\right)$ の BMI 混合物量依存 性に関する三系列間の差として， $E^{\prime}$ の場合には，E－MTAT 系 と E・MTAIC 系はほぼ同様の挙動を示し, E・MDAP 系と比 べて, 若干大きな上昇傾向を示した。 また， $T_{\alpha}$ の場合には，そ の上年挙動は $\mathrm{E} \cdot \mathrm{MTAT}>\mathrm{E} \cdot \mathrm{MTAIC}>\mathrm{E} \cdot \mathrm{MDAP}$ の順に大き かった.

Fig. 3 に各ブレンドについて, 転移がほぼ完了したと見做さ れる $T_{\alpha}+40^{\circ} \mathrm{C}$ の温度に打ける相対弾性率 $E_{\mathrm{rel}}^{\prime}$ (エポキシ樹脂 に対するブレンドの弾性率の比）の BMI 混合物の組成依存性を 示す. $E^{\prime}{ }_{\mathrm{r} 1 \mathrm{1}}$ は BMI 混合物の濃度が, 約 $30 \sim 40 \%$ 付近から急激 に増加した。 このような挙動は通常の粒子充填系と異なり, これ までに報告されているように IPN の挙動と類似している ${ }^{10)}$.な 拈, $\mathrm{E} \cdot \mathrm{MDAP}$ 系は他の二つの系と比べて若干高濃度側で急激

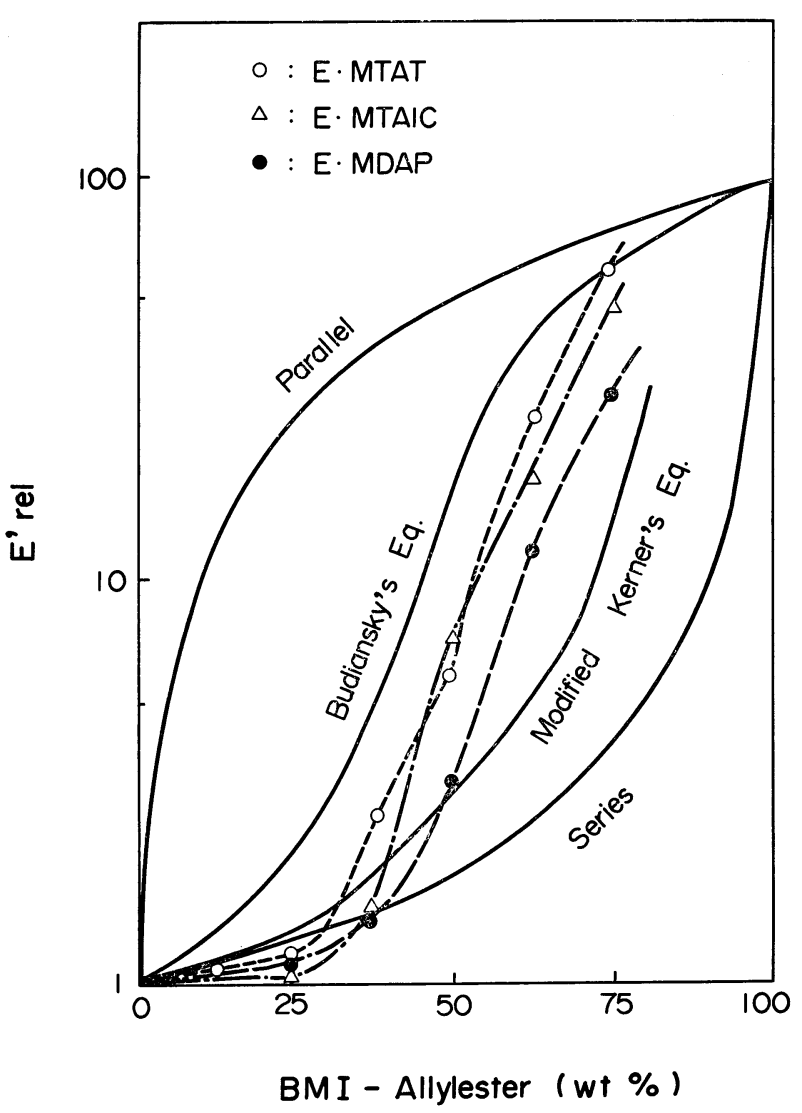

Fig. 3 Relative moduli vs weight fraction of BMI-allylester.

な増加の開始を示した. IPN の力学挙動を記述するモデルとし ていくつか存在するが， Phase domain 間の相互作用を考慮した 式(1)の Budiansky 式は11)，比較的良好な適合性を示すとされて いる ${ }^{12)}$.

$$
\frac{V_{1}}{1+\varepsilon\left(G_{1} / G-1\right)}+\frac{V_{2}}{1+\varepsilon\left(G_{2} / G-1\right)}=1
$$

$$
\begin{aligned}
& \text { ここで, } \\
& \qquad \varepsilon=\frac{2(4-5 \nu)}{15(1-\nu)}
\end{aligned}
$$

ここで，Gはずり弾性率，Vは体積分率，およびレはポアソン 比で, 添字字 1 扣よび 2 は成分物質を表す。計算にあたって, エ ポキシ樹脂とビスマレイミド・アリルエステル共重合体のポアソ ン比を, それぞれ 0.5 拉よび 0.35 とし, 複合体のそれは加成則に 従うとした。な扣，比較のため粒子分散系で一般的な修正 Kerner 式 ${ }^{13)}$, 扣よび複合体のモジュラスの上限扣よび下限を与える並列 結合, 执よび直列結合式についても計算した。

修正 Kerner 式は,

$$
\frac{E^{\prime}}{E_{1}^{\prime}}=\frac{1+A B \Phi_{2}}{1-B \Psi \Phi_{2}}
$$

ここで,

$$
\begin{aligned}
& B=\frac{E_{2}{ }^{\prime} / E_{1}{ }^{\prime}-1}{E_{2}{ }^{\prime} / E_{1}{ }^{\prime}+A}, \quad A=\frac{7-5 \nu_{1}}{8-10 \nu_{1}} \\
& \Psi=1+\left(\frac{1-\Phi_{\mathrm{m}}}{\Phi_{\mathrm{m} 2}}\right) \Phi_{2}
\end{aligned}
$$


で与えられ， $\Phi_{\mathrm{m}}$ は最密充填率を示す.

並列結合式は,

$$
E^{\prime}=E_{1} \Phi_{1}+E_{2} \Phi_{2}
$$

で与えられまた直列結合式は，

$$
\frac{1}{E^{\prime}}=\frac{\Phi_{1}}{E_{1}{ }^{\prime}}+\frac{\Phi_{2}}{E_{2}{ }^{\prime}}
$$

で与えられる．ここで，式(2)〜(4)に拈ける添完 1 および 2 は， それぞれ媒体相拉よび分散相を示す。

実験值はいずれの系もほぼ Budiansky 式と修正 Kerner 式の間 にあるが，曲線の形状としては前者に近い，これは $30 \%$ 近辺から のモジュラスの急激な上䄯が，この組成域で両成分間に相互侵入 (Phase inversion) が起こっている事を示し，IPN 形成効果によ るものと考えられる ${ }^{10)}$ Ｅ－MDAP 系の場合，他の二者に比べ て IPN 化が起こり難くなっている。これはDAP が2官能性で あるのに対して TAT 和よび TAIC は 3 官能性であり, IPN 化 度は系内の化学的な橋かけ密度に依存する事を示している.

各系列に和いて, 主分散温度 $\left(T_{\alpha}\right)$ は BMI 混合物量の増加と ともに高温側ヘシフトした. E・MTAIC-100および E · MDAP100 の場合に, 室温から $400^{\circ} \mathrm{C}$ を゙測定温度範囲でなんらの分散 も観測されなかった，従って，ブレンド系に拈ける主分散は，エ

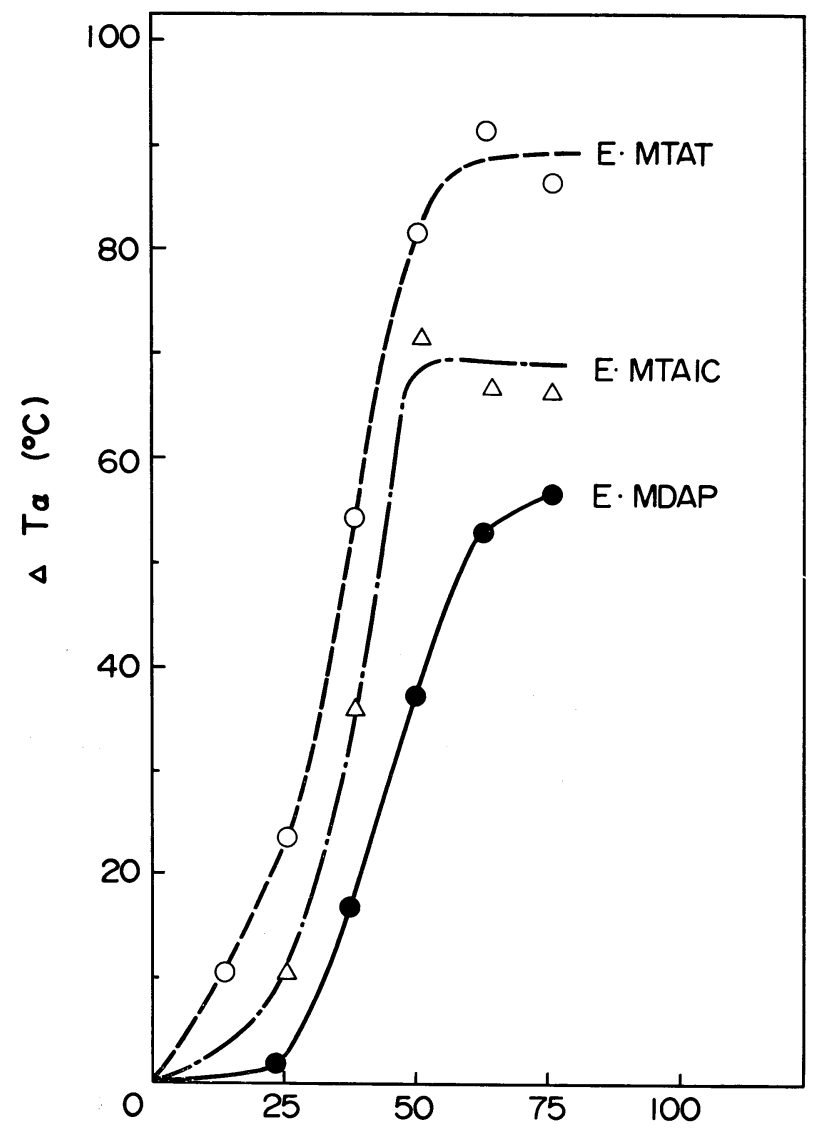

BM I-Allylester $(w t \%)$

Fig. 4 Dependence of the increment in $T_{\alpha}$ on weight fraction of BMI-allylester.
ポキシ樹脂の束縛されたセグメント運動によるるのと見做される. $\mathrm{T}_{\alpha}$ の BMI 混合物量依存性は, 最初急激に増加し, 次いで上限 值に収束する傾向を示した (Fig. 4). このようなS 字型の挙動は,

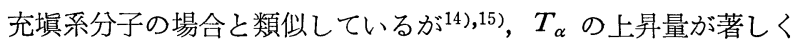
大きい事が特徴的である. Fig. 4 亿示すように， $T_{\alpha}$ の上昇挙動 は各系列に执いて異なり，上限值は $\mathrm{E} \cdot \mathrm{MTAT}>\mathrm{E} \cdot \mathrm{MTAIC}>$ $\mathrm{E} \cdot \mathrm{MDAP}$ の順に大きくなった，各ブレンド系に括ける $T_{\alpha}$ 上 界挙動の違いは, アリルエステルの違いによるものであり, TAT と TAIC は官能基数は同じであるが，化学構造が異なる。一方， DAP は TAT と化学構造は類似しているが, 官能基数が TAT と TAIC より少ない。この事から， $T_{\alpha}$ の上年は BMI ・ アリル エステル共重合体によるからみ合い效果と相互作用効果の二つの 寄与から生じたものと考えられる。

からみあい効果に関しては, 前報に招いて $T_{\alpha}$ と橋かけ密度 との関係が, いずれの系列に対しても, 橋かけ高分子のガラス転 移温度 $\left(T_{\mathrm{g}}\right)$ に関する関係式, $T_{\mathrm{g}}=K_{1} \ln K_{2} \nu\left(K_{1}\right.$ 抢よび $K_{2}$ は 定数）に従って ${ }^{16}$ 表示可能であり， $T_{\alpha}$ の上昇に対し，橋かけに よる寄与分も含まれている事を示唆した ${ }^{6)}$. しかし, Fig. 4 の $T_{\alpha}$ 上限值に怙ける各系列間の差は, 橋かけ効果により説明できず, 各アリルエステルの化学構造の違い, すなわちエポキシ樹脂と BMI ・アリルェステル 共重合体成分間の相互作用効果により生 じたものと考えられる.

二つの高分子間の相溶性は, 溶解度パラメータ值 $(\delta)$ によっ て評価できる，極性高分子の場合には，Hansen の方法によって ঠの成分を求める事が望ましい17)。すなわち,

$$
\begin{aligned}
& \delta^{2}=\delta_{\mathrm{d}}{ }^{2}+\delta_{\varepsilon}{ }^{2}+\delta_{\mathrm{h}}{ }^{2} \\
& \delta_{\mathrm{a}}{ }^{2}=\delta_{\varepsilon}{ }^{2}+\delta_{\mathrm{h}}{ }^{2}
\end{aligned}
$$

ここで, $\delta_{\mathrm{d}}, \delta_{\varepsilon}$ 抢よび $\delta_{\mathrm{h}}$ はれれぞれ分散, 極性就よび水素結 合による成分を表し， $\delta_{\mathrm{a}}$ は吸引成分を示すままた， $\delta_{\varepsilon}$ および $\delta_{\mathrm{h}}$ は次式によって求められる18).

$$
\begin{aligned}
& \delta_{\varepsilon}^{2}=\frac{R T}{V_{\mathrm{m}}} \cdot \frac{(\varepsilon-1)(\varepsilon-n)}{\varepsilon(n+2)} \\
& \delta_{\mathrm{h}}{ }^{2}=\frac{5000 N}{V_{\mathrm{m}}}
\end{aligned}
$$

ここで, $\varepsilon$ は誘電率, $n$ は屈折率, $N$ は 1 分子中の水酸基の数, $V_{\mathrm{m}}$ は分子容, $R$ はガス定数扔よびTは温度である. 二つの高分 子に拈けるそれぞれの $\delta_{\mathrm{d}}$ 特よび $\delta_{\mathrm{a}}$ 同志の差が小さいほど相溶 性が增す事になる。な拉，より相溶性の程度を表示するパラメー タとして, Hildebrand による混合のエンタルピーが $\delta$ の差の 2 乘に比例する事から ${ }^{19)}$ ，それらの值について各系列で求めた結果 を Table 1 飞示す. Table 1 から, 相溶性は E. MTAT ZE. MTAIC $>$ E ・ MDAP の順に良くなり，Fig. 4 の結果と対応し ている.

ここで観察された BMI 混合物の添加による主分散温度の上昇 量は，単なるフィラー効果とするにはあまりに大きすぎる. Fig. 2 に示す様に, $\tan \delta$ 曲線は BMI アリルェステル混合物量の増 加とともに, 非常にブロードとなって行った. いま, 主分散領域 での $\tan \delta$ 対温度曲線下の面積を各ブレンドについて求めると, いずれの試料に执いても両成分の加成則より大きくなる事が認め られた。この事から主分散に関し，BMI・アリルエステル共重合 体の分子鎖セグメントの一部が，エポキシ樹脂のセグメント運動 
Table 1 Calculated components of the solubility parameter and interaction between epoxy resin and BMI allylester.

\begin{tabular}{lcccccccc}
\hline & $\varepsilon_{0}^{\mathrm{a})}$ & $n_{\mathrm{D}}{ }^{\mathrm{b})}$ & $V_{\mathrm{m}}$ & $\delta$ & $\delta_{\mathrm{d}}$ & $\delta_{\mathrm{a}}$ & $\begin{array}{c}\left(\delta_{\mathrm{dE}}-\right. \\
\left.\delta_{\mathrm{dB}}\right)^{2}\end{array}$ & $\begin{array}{c}\left(\delta_{\mathrm{aE}}-\right. \\
\left.\delta_{\mathrm{aB}}\right)^{2}\end{array}$ \\
\hline Epoxy resin & 4.1 & 1.538 & 473 & 9.6 & 9.5 & 1.4 & - & - \\
$\mathrm{BMI} \cdot \mathrm{TAT}$ & 6.5 & 1.552 & 525 & 9.0 & 9.0 & 0.91 & 0.25 & 0.24 \\
$\mathrm{BMI} \cdot \mathrm{TAIC}$ & 5.1 & 1.572 & 471 & 9.2 & 9.2 & 0.76 & 0.09 & 0.41 \\
$\mathrm{BMI} \cdot \mathrm{DAP}$ & 4.1 & 1.549 & 472 & 8.6 & 8.6 & 0.67 & 0.81 & 0.53 \\
\hline
\end{tabular}

a) Measured by bridge method.

b) Measured at $25^{\circ} \mathrm{C}$ by Abbe refractometer.

に関与しているものと見做すと，この様な大きな $T_{\alpha}$ 上䒜が説明 可能となる. ここで, エポキシ樹脂中への BMI・アリルエステ ル共重合体の分子混合の程度を, 次式の完全相溶系の場合の共重 合体の $T_{\mathrm{g}}$ 予測式により評価を試みた。 $T_{\mathrm{g}}$ の代わりに $T_{\alpha}$ とし $\tau$,

$$
\frac{1}{T_{\alpha}}=\frac{w_{1}}{T_{\alpha 1}}+\frac{w_{2}}{T_{\alpha 2}}
$$

ここで，wは重量分率， $T_{\alpha 1}$ 㧊よび $T_{\alpha 2}$ はそれぞれエポキシ樹

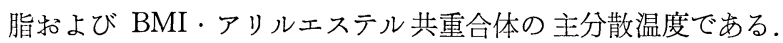
現在の実験に括いて，E・MDAP-100 拈よび E・MTAIC-100 の主分散温度が観測されなかったため，それぞれの熱分解開始温 度である $380^{\circ} \mathrm{C}$ 抢よび $410^{\circ} \mathrm{C}$ を利用した。エポキシ樹脂中への $\mathrm{BMI}$ ・アリルェステル成分の分子混合の程度について計算した 結果を, Table 2 亿示す. 表からエポキシ樹脂は, BMI・アリル エステル共重合体と部分相溶性であり, ブレンドは不均質構造か らなる事が判る。 また，50\%の組成において最大の分子混合が起 こっている事を示している。この様な結果は，この組成近辺で両 成分間の網目鎖の相互貫通が十分行われた結果もたらされたもの と結論できる。な技，E－MTAT 系の場合に, BMI・トリアリ ルトリメリテート (TAT) 共重合体に执いて約 $380^{\circ} \mathrm{C}$ の温度で主 分散が観察されたが，ブレンドでは他の系と同様，どの成分でも 共重合体による転移は現れなかった。これは BMI 混合物の低濃 度側では, その転移が小さいため, また高濃度側ではエポキシ樹 脂成分との部分相溶性により幅広い易動性の分布となって，それ

Table 2 Evaluation of the mixing degree of BMI-allylester components into the epoxy resin, according to $1 / T_{\alpha}=w_{1} / T_{\alpha 1}+w_{2} / T_{\alpha 2}$.

\begin{tabular}{lccc}
\hline & $T_{\alpha \mathrm{obs}}\left({ }^{\circ} \mathrm{C}\right)$ & $T_{\alpha \mathrm{ca} .1}\left({ }^{\circ} \mathrm{C}\right)$ & $\operatorname{mix}(\%)$ \\
\hline E.MTAT-25 & 167 & 186 & 52 \\
E.MTAT-50 & 225 & 236 & 90 \\
E.MTAT-75 & 230 & 299 & 63 \\
E.MTAIC-25 & 154 & 193 & 20 \\
E.MTAIC-50 & 215 & 254 & 70 \\
E.MTAIC-75 & 210 & 333 & 53 \\
E.MDAP-25 & 145 & 186 & 0 \\
E.MDAP-50 & 180 & 236 & 42 \\
E.MDAP-75 & 200 & 299 & 43 \\
\hline
\end{tabular}

ぞれ BMI・アリルエステル共重合体成分による単属の分散が現 れなかったものと考兄られる。

\section{$3 \cdot 2$ 引張り性質亡熱分解特性}

IPN 形成効果のひとつとして, 前節に执いてガラス転移に相当 する主分散温度の効率的な向上が示されたが，他の諸性質につい ても向上效果が期待される. 特に, Frisch らは実用性質として 引張り性質と熱分解特性に関し, 個々の成分単体よりも大きな值 を示寸相乗効果の現れる場合がある例を報告している7

Fig. 5 に, 室温, $150^{\circ} \mathrm{C}$ 抽よび $200^{\circ} \mathrm{C}$ に抹ける引張り強度および 伸びの BMI 混合物量依存性を示す. BMI・アリルテステル共重 合体単体については, 試料が極めて脆いため引張り試験が出来な かったが，その值はかなり小さいものと判断される。図から室温 の場合に，引張り強度执よび破断伸びとも， BMI 混合物量 $25 \%$ で極小が現れ，次いで50\%の組成で個々の成分単体よりも若干大 きい極大值が現れた. BMI混 合物の低濃度側では, 低弾性率のエ ポキシ樹脂マトリックスに対する，上り高い弾性率の BMI・ア リルエステル共重合体によるフィラー効果と見做すと, Nielsen ${ }^{20)}$ やその他の理論 ${ }^{21), 22}$ によっても予測されるょうに，引張り強度 や破断伸びはマトリックスより減少する事になり，また50\%近辺 の濃度では, 相互貫通高分子網目 (IPN) )形成による見かけの 橋かけ密度の增加効果によると見做すと, 引張り強度は橋かけ密 度に比例する事から ${ }^{8)}$, 強度が增加し, ここで観察された極小や 極大が説明可能となる。しかし，一般に両成分がガラス状態にあ る場合には, ブレンドの破壊性質は系内の欠陥や不均質さなどに
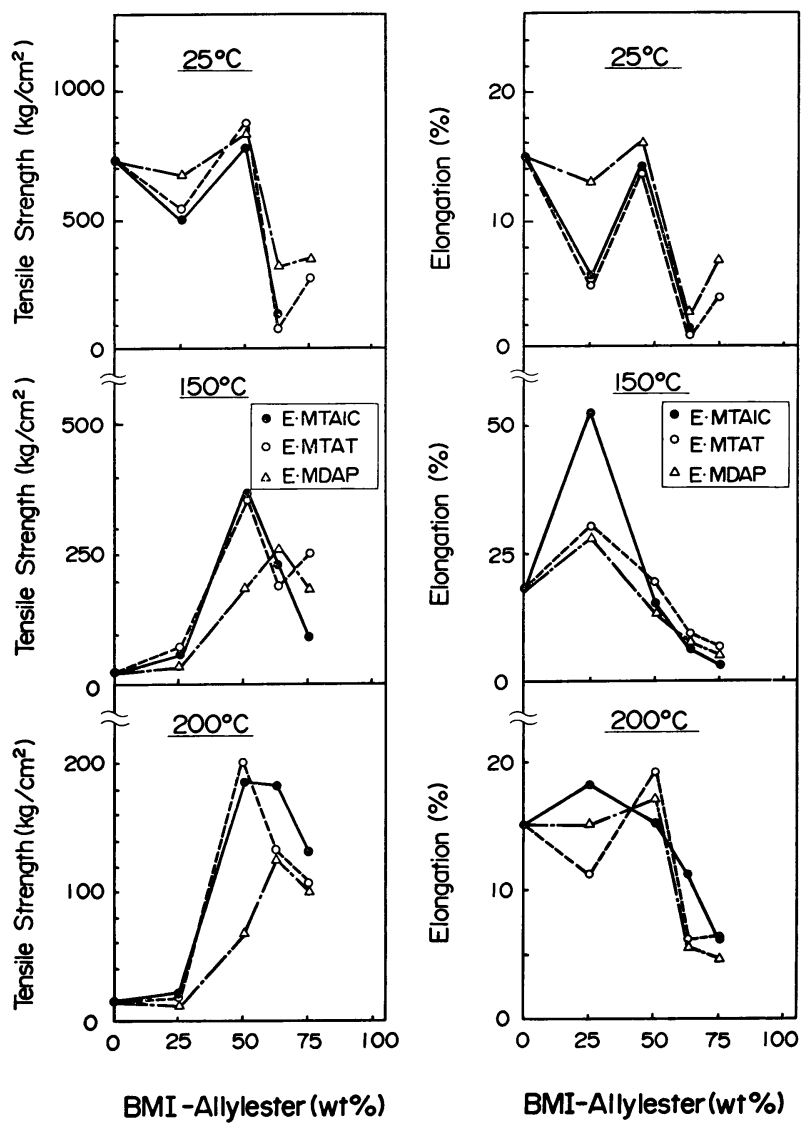

BMI-Allylester $(w t \%)$

Fig. 5 Tensile strength and elongation at break vs weight fraction of BMI-allylester at $25,150,200^{\circ} \mathrm{C}$. 
大きく支配され，橋かけによる効果は余り出てこないものと考兄 られる. このため IPN 効果を期待するには, ブレンド構造に付 加的な補強が達成されやすい系として，一方の成分がガラス状態, 他方の成分がゴム状態にある場合が好ましく，実際的にもこの様

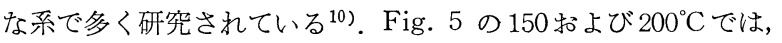
室温の場合と比べ 引張強度に抒いて顕著な相乗効果が，50\%近 辺の濃度で観察された。このような大きな強度の増加は，単に IPN 化による物理的な橋かけ（からみあい）密度の增加により もたらされたものとしては大きすぎる。したがって，より実際的 な強度発現機構として，ゴム状態にあるエポキシ樹脂成分にとっ て，兮ラス状態の BMI ・アリルェステル共重合体成分による補 強効果，またガラス状態にある BMI - アリルエステル共重合体 成分にとって，ゴム状態のエポキシ樹脂成分による脆性の改善と いうブレンド構造に扔ける相互補強効果が，前記の IPN 化によ る相溶性の向上により強調されて, ブレンドとしての強度向上が もたらされたものと考光られる。

Fig. 6 に, 各試料系について 熱重量残存率の温度依存性を示

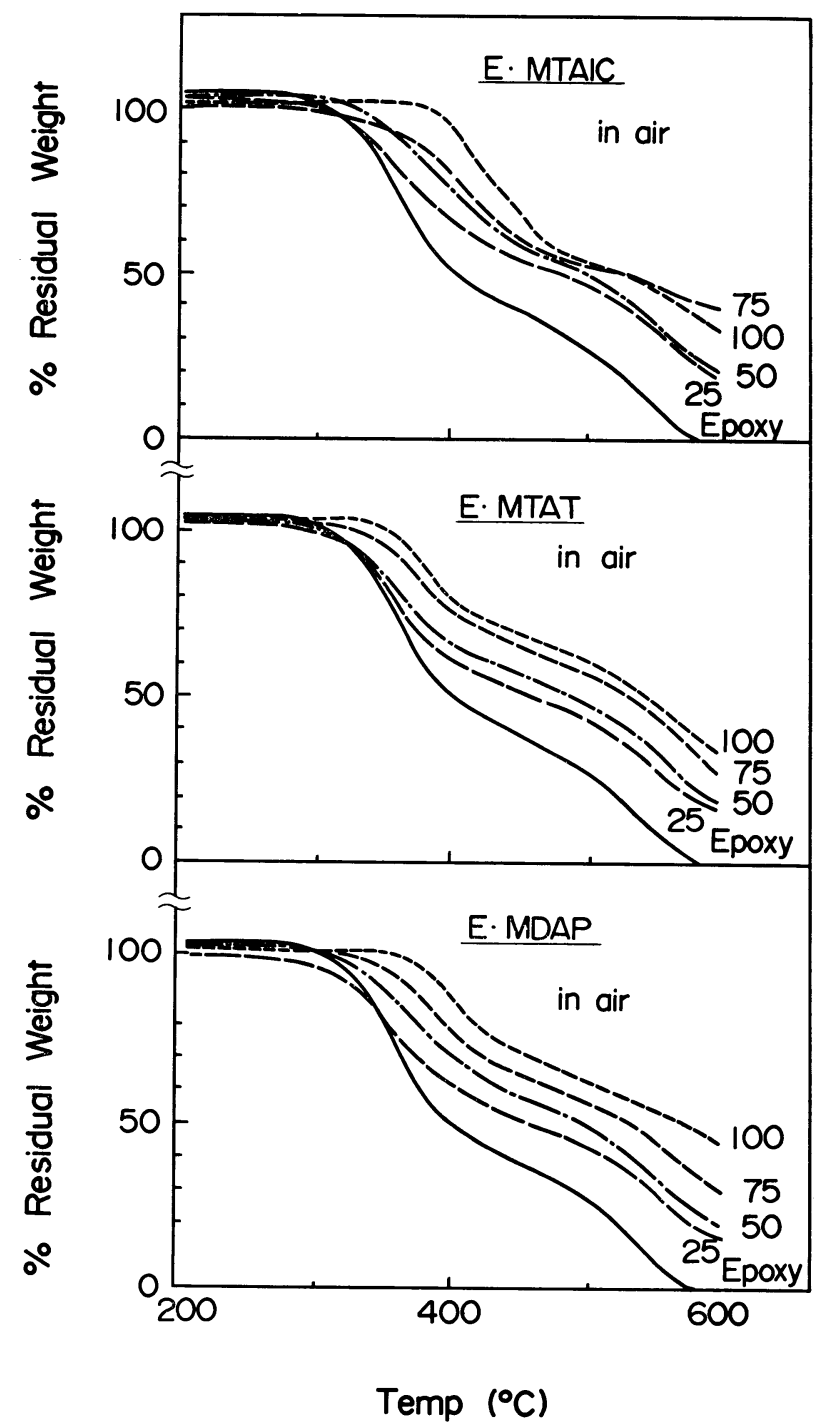

Fig. 6 Thermogravimetric curves for the degradation of $\mathrm{E} \cdot \mathrm{MTAIC}, \mathrm{E} \cdot \mathrm{MTAT}$, and E.MDAP series in air.
す.どの系列においても，ブレンドはすべてエポキシ樹脂硬化物 と各 BMI・アリルエステル共重合体の熱重量損失曲線の範囲内 にあり, 顕著な IPN 効果は認められなかった。そこで各試料に ついて, 熱分解反応の活性化エネルギ $-\Delta E$ を, 次式により熱重 量損失曲線から求めてみた 济 $^{23}$.

$$
\ln [\ln (1-\alpha)]=\frac{\Delta E}{R T_{1}} \times \frac{100\left(T-T_{\mathrm{S}}\right)}{\left(T_{2}-T_{1}\right)}
$$

ここで， $\alpha$ は温度 $T$ での熱重量損失， $T_{\mathrm{s}}$ は最高分解速度温度， $T_{1}$ 扣よび $T_{2}$ はそれぞれ開始扣よび終了分解温度，および $G$ は定 数である. Fig. 7 に, $\Delta E$ についての計算結果を， $T_{\mathrm{s}}$ とともに 示す. $\Delta E$ については，E・MTAIC と E・MDAP 系で，また $T_{\mathrm{s}}$ については，E・MTAIC 系で，それぞれ 50〜 75\%の BMI 混合物濃度で加成則より上にあり，相乗効果が認められた。エポ キシ樹脂硬化物の熱分解は, 分子鎖中のエーテル結合とェステル 結合の切断，招よび炭化縮合反応が同時に起こる一段階反応とい われている24)．Fig. 7 の結果は， BMI・アリルエステル共重合 体の網目分子鎖との相互貫通が，熱分解により切断されたエポキ シ樹脂分子鎖の系外への散逸を抑える働きをしている事を示唆し ている.

\section{4. 結 論}

エポキシ樹脂とビスマレイミド/アリルエステル 樹脂とから, 同時重合により，相互貫通高分子網目 (IPN) 試料を作成した. その動的粘弾性研究に打いて, 高温ゴム弾性率の組成依存性が, Budiansky 式に近い挙動を示し，IPN の形成が示唆された。 た，IPN 効果により中間の組成領域に执いて，両成分間で最大 の分子混合が起こり，ガラス転移温度が効率良く上年する事が判 った，さらに，IPN 効果は実用的性質としての引張り強度に持 いて，成分単体よりも大きくなる相乗作用をもたらし，また熱分 解特性も改善させる事が判った，得られた知見は無溶剤タイプで, 耐熱性と機械的性質の良い複合材料用マトリックスレジン開発の ための基礎的指針になるものと期待される。

平成元年10月18日, 第37回レオロジー討論会（福岡）にて発表 した.

\section{文献}

1) Bergain M, et al., British Patent 1190718, to Rhone Poulenc (1978).

2) Varma I, Guputa A, Sangita, J. Polym. Sci. Polym. Lett. Fd., 20, 621 (1982).

3) Varma I, Guputa A, Sangita, Varma DS, J. Appl. Polym Sci., 28, 191 (1983).

4) Stenzenberger H, British Patent 1501606, to Technochemie (1976).

5) Stenzenberger H, Herzog M, Romer W, Scheiblich R, Keeves NJ, Br. Polym. J., 15, 1 (1983).

6) Fukami A, Iisaka K, Etoh S, J. Macromol. Sci., Phys., B28(2), 251 (1989).

7) Frisch KC, Klempner D, Migdal S, J. Polym. Sci. Polym. Chem. Ed., 12, 885 (1974).

8) Frisch KC, Klempner D, Mukherjee SK, J. Appl. 

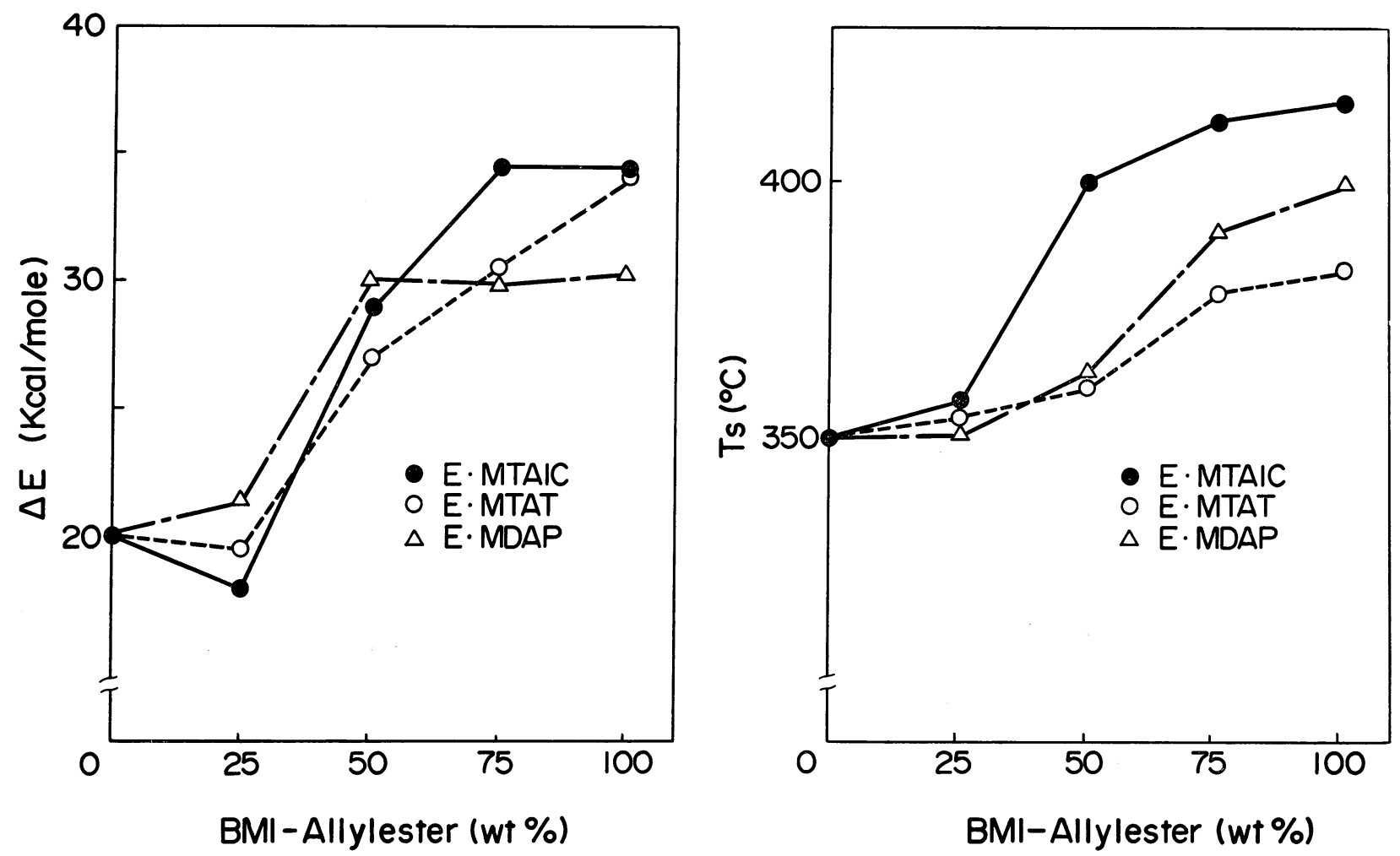

Fig. 7 Activation energy for the thermal degradation and maximum decomposition temperature vs weight fraction of BMI-allylester.

Polym. Sci., 18, 689 (1974).

9) Frisch KC, Klempner D, Antczak T, J. Appl. Polym. Sci., 18, 683 (1974).

10) Sperling LH, J. Polym. Sci., Macromol. Rev., 12, 141 (1977).

11) Budiansky B, J. Mech. Phys. Solids, 13, 223 (1965).

12) Kim SC, Klempner D, Frisch KC, Frisch H.L., Macromolecules, 10, No. 6, 1187 (1977).

13) Lewis TB, Nielsen LE, J. Appl. Polym. Sci., 14, 1449 (1970).

14) Droste DH, DeBenedetto AT, J. Appl. Polym. Sci., 13, 2149 (1969).

15) Iisaka K, Shibayama K, J. Appl. Polym. Sci., 22, 1321 (1978).

16) Shibayama K, Suzuki Y, J. Polym. Sci., A-3, 2637
(1965).

17) Hansen CM, J. Paint Technol., 39, 104 (1967).

18) Hansen CM, SkaarupK., J. Paint Tehnol., 39, 511 (1967).

19) Hildebrand JH, Scott RL, "Solubility of Nonelectrolytes", Dover, New York (1963).

20) Nielsen LE, J. Apple. Polym. Sci., 10, 97 (1966).

21) Leidner J, Woodhams RT, J. Appl. Polym. Sci., 18, 1639 (1974).

22) Chow TS, J. Polym. Sci., Polym. Phys. Ed., 20, 2103 (1982).

23) Bandal R, Sahoo J, Angewandte Macromol. Chem., 79, 125 (1979).

24) Fleming, GJ, J. Appl. Polym. Sci., 10, 1813 (1966). 